ISSN 0103-8478

\title{
Ripening and shelf life of 'BRS Caipira' banana fruit stored under room temperature or refrigeration
}

\author{
Amadurecimento e vida útil de frutos de bananeira 'BRS Caipira' \\ armazenados em temperatura ambiente ou refrigeração
}

\author{
Orjana Santos Lima ${ }^{I}$ Elaine Goes Souza ${ }^{I I}$ \\ Edson Perito Amorim ${ }^{\mathrm{II}}$ Márcio Eduardo Canto Pereira ${ }^{\mathrm{I}{ }^{*}}$
}

\section{ABSTRACT}

BRS Caipira variety, internationally known as 'Yangambi $\mathrm{km}$ 5', is an alternative to meet the demand of 'Maçã'type fruit due to its resistance to Panama disease. This study had the objective of generating information about 'BRS Caipira' fruit ripening and cold storage potential. For the ripening study fruits were stored under room temperature conditions $\left(25 \pm 2{ }^{\circ} \mathrm{C} / 58 \pm 6 \%\right.$ U.R.) and assessed for postharvest life evaluation and characterization of seven maturity stages based on peel color: completely green - MS1; green with yellow traces - MS2; more green than yellow - MS3; more yellow than green - MS4; yellow with green tips - MS5; completely yellow - MS6; yellow with brown spots - MS7. For the cold storage potential study, fruits at MS1 were cold stored $\left(14 \pm 1^{\circ} \mathrm{C} / 53 \pm 2 \%\right.$ U.R.) for 28 days. Weekly, fruits were transferred to room temperature to ripen until MS6 when were assessed for quality attributes. Ripening of 'BRS Caipira' fruit was characterized as slow between MS1 and MS2 (averaging five days), then fast between MS2 and MS6 (up to four days in average), and undergoing determinant changes between MS6 and MS7: pulp yield reached $80 \%$, titratable acidity reduced by $50 \%$ and ratio increased by $78 \%$. Cold storage extended shelf life by up to 19 days as compared with control, without visible symptoms of chilling injury, although tends to reduce soluble solids in ripe fruit. Maximum recommended time for storage of 'BRS Caipira' fruit at $14^{\circ} \mathrm{C}$ is 21 days, since it allows a few more days under room temperature until fruit reach MS6.

Key words: Musa spp., 'Yangambi km 5', cold storage, maturity stage.

\section{RESUMO}

A variedade BRS Caipira, internacionalmente conhecida como 'Yangambi km 5', é uma alternativa para atender a demanda de frutos do tipo Maçã, devido à sua resistência ao mal-do-Panamá. Este estudo objetivou gerar informações sobre o amadurecimento e o potencial de armazenamento refrigerado de frutos de 'BRS Caipira'. Para o estudo do amadurecimento, frutos foram armazenados sob temperatura ambiente $\left(25 \pm 2^{\circ} \mathrm{C} / 58 \pm 6 \%\right.$ U.R.) e avaliados para vida pós-colheita e caracterização de sete estádios de maturação baseados na cor da casca: completamente verde - MS1; verde com traços amarelos - MS2; mais verde que amarelo - MS3; mais amarelo que verde - MS4; amarelo com pontas verdes - MS5; completamente amarelo - MS6; amarelo com manchas marrons - MS7. Para o estudo de potencial de armazenamento refrigerado, frutos em MS1 foram armazenados em câmara fria $\left(14 \pm 1^{\circ} \mathrm{C} / 53 \pm 2 \%\right.$ U.R.) por 28 dias. Semanalmente, uma amostra de frutos era retirada para a temperatura ambiente e avaliados para atributos de qualidade. $O$ amadurecimento de frutos de 'BRS Caipira' foi caracterizado como lento entre MS1 $e$ MS2 (cinco dias em média), rápido entre MS2 e MS6 (até quatro dias em média), e que passa por alterações determinantes entre MS6 e MS7: rendimento em polpa atingiu 80\%; acidez reduziu pela metade; e ratio aumentou $78 \%$. A refrigeração prolongou a vida útil dos frutos em até 19 dias em relação ao controle, sem sintomas visíveis de danos por frio, embora tenda a reduzir o teor de sólidos solúveis nos frutos maduros. O período máximo recomendado para armazenagem de frutos de 'BRS Caipira'a $14^{\circ} \mathrm{C} e ́$ de 21 dias, tempo que permitiria mais alguns dias em temperatura ambiente para os frutos atingirem o estádio MS6.

Palavras-chave: Musa spp., 'Yangambi km 5', armazenamento refrigerado, estádio de maturação.

\section{INTRODUCTION}

A significant part of the banana production in Brazil, which is close to seven million tons (IBGE, 2012), is lost after harvest. This is a result of a number of factors including lack of training of commercialization agents in fruit ripening and careful handling. Several injuries that depreciate the appearance of the product lower the banana value

'Universidade Federal do Recôncavo da Bahia (UFRB), Cruz das Almas, BA, Brasil.

"Embrapa Mandioca e Fruticultura, Rua Embrapa, s/n, CP 007, 44380-000, Cruz das Almas, BA, Brasil. E-mail: marcio.pereira@embrapa.br.

*Autor para correspondência. 
in the internal market and in detriment of exports (LICHTEMBERG \& LICHTEMBERG, 2011).

Knowing information about fruit ripening is essential to guarantee fruit quality and optimize its postharvest life. During storage in tropical environments with higher average temperatures, bananas ripen quickly and have a short postharvest life and commercialization window. Cold storage rises as an alternative to extend the pre-climacteric phase, in which fruit are still green, and therefore to extend its postharvest life (MARTINS et al., 2007). The minimum safe temperature for banana storage depends on the variety and maturity stage, but the best range is between $13^{\circ} \mathrm{C}$ and $15^{\circ} \mathrm{C}$ (PAYASI \& SANWAL, 2010).

The banana is harvested in its physiological maturity and its full ripening depends on ethylene, a plant regulator that triggers several transformations in the fruit after harvest, including those related to fruit color and flavor (XIAO et al., 2013). Peel color, which is completely green after harvest and progresses to yellow during ripening, usually is well correlated with fruit maturity, meaning an important parameter for shelf life and for the consumers' decision to purchase the fruit or not (MATSUURA et al., 2004).

BRS Caipira variety, internationally known as 'Yangambi km 5', is a triploid AAA resistant to black and yellow Sigatokas and to Panama disease (SILVA et al., 2004), besides being a source of resistance to nematodes (DOCHEZ et al., 2013). The physical and organoleptic characteristics of the fruit are similar to those of 'Maçã' and makes it a possible substitute of this variety which cultivation in Brazil is restrict due to its high susceptibility to Panama disease. This variety was first recommended for the Amazon region (SILVA et al., 2003) but it has been recommended for organic production systems as well due to the resistance to important banana diseases (CORDEIRO \& MATOS, 2010). Although this variety is an alternative to banana production in the mentioned areas, information on its postharvest physiology and handling are very scarce but necessary for proper commercialization. Therefore, this study had the objective of generating information about 'BRS Caipira' fruit ripening and cold storage potential.

\section{MATERIAL AND METHODS}

This study was conducted in the Laboratório de Fisiologia e Pós-colheita at Embrapa Mandioca e Fruticultura, located in Cruz das Almas, Bahia state, Brazil. Bunches of 'BRS Caipira' from first cycle plants were harvested approximately within 130 days after inflorescence emergence from an experimental area in the same institution and fruit used for experimental setup. Each experiment was set with fruit from two bunches, discarding the first and last hands of each bunch.

\section{Characterization of physical attributes}

An initial group of fruits at maturity stage 1 (completely green peel) from each recently harvested bunch was used for characterization of physical attributes (DADZIE \& ORCHARD, 1997): fruit weight, external length and diameter; pulp weight and diameter; peel thickness; pulp yield (\% w/w).

Ripening and postharvest life study
Under room temperature conditions ( $25 \pm 2{ }^{\circ} \mathrm{C} / 58 \pm 6 \%$ U.R.), an experiment was conducted in the beginning of November 2011 and repeated in the end of November 2011. In each occasion, selected fruits were separated into two groups. The first group, a sample of 20 fruits made by groups of four or five fruits from each usable hand, was used exclusively to determine postharvest life, observing the time (days) to reach each maturity stage. The color chart from Von Loesecke, adopted by the regulations of banana classification in Brazil (PBMH \& PIF, 2006), was used as basis to determine each maturity stage based on peel color: completely green - MS1; green with yellow traces - MS2; more green than yellow MS3; more yellow than green - MS4; yellow with green tips - MS5; completely yellow - MS6; yellow with brown spots - MS7. The second group of fruits was randomly placed on styrofoam trays on shelves and allowed to ripen for the characterization of the seven maturity stages. Four fruit from each maturity stage were individually assessed for physical attributes (DADZIE \& ORCHARD, 1997): fruit weight, external length and diameter; pulp weight and diameter; peel thickness; pulp to peel ratio; and pulp yield $(\% \mathrm{w} / \mathrm{w})$. Then the pulp of each individual fruit was mixed with distilled water (1:1 ratio) using a domestic blender. Samples from this homogenized pulp were used for the following analyses (DADZIE \& ORCHARD, 1997): soluble solids content (SS); titratable acidity (TA); ratio and $\mathrm{pH}$.

\section{Cold storage potential study}

Under cold storage $\left(14 \pm 1^{\circ} \mathrm{C} / 53 \pm 2 \%\right.$ R.H. $)$, the experiment was conducted in November 2011 and repeated in December 2011. In each occasion, groups of fruits recently harvested (completely green peel) were stored in a cold room for 28 days. Weekly, fruits were transferred to room temperature, the time (days) 
to reach MS6 (completely yellow peel) was observed and fruits were assessed for SS and TA analyses (DADZIE \& ORCHARD, 1997).

The experiments were conducted in a completely randomized design, with seven (maturity stages) or five treatments (days under cold storage), respectively for experiments under room temperature or cold storage, with four replicates. For each experiment, data from both occasions were combined and analyzed by ANOVA and the means compared by Tukey's test at $5 \%$ probability. Statistical analysis was performed by the statistical package Sisvar (FERREIRA, 2011).

\section{RESULTS AND DISCUSSION}

Characterization of physical attributes

'BRS Caipira' banana fruit assessed in this study weighted $96 \mathrm{~g}$ in average (Table 1 ), heavier than those cultivated in Lavras - MG region (PEREIRA et al., 2003), but similar to those from Cruz das Almas previously reported (SILVA et al., 2004). Average fruit length $(14 \mathrm{~cm})$ and diameter $(35 \mathrm{~cm})$ were characteristics of a short and thick format fruit, which is observed for Maçã banana cultivars (CARVALHO et al., 2011; MENDONÇA et al., 2013). Since their diameter is over $32 \mathrm{~mm}$, they fit in the best category for Maçã group bananas according to Brazilian classification standards (PBMH \& PIF, 2006).

\section{Ripening and postharvest life study}

Fruit ripening under room temperature $\left(25 \pm 2{ }^{\circ} \mathrm{C} / 58 \pm 6 \%\right.$ R.H.) was slow until MS2, within five days in average (Table 2). Then, until MS6, when the peel is completely yellow, changes occurred rapidly, within an interval of less than four days. MS7 was reached in approximately 11 days of storage, which is longer than fruit from several other genotypes evaluated under Cruz das Almas conditions and ripened at $21^{\circ} \mathrm{C}$ (CERQUEIRA et al., 2002).

Typical ripe 'BRS Caipira' fruit are short, have thin peel and good pulp yield. These characteristics were observed in the last maturity stages, mainly MS7. Pulp to peel ratio increased significant and gradually until MS6 (Table 2), a clear indication of higher weight loss from the peel than from the pulp. This ratio increased sharply in the last maturity stage when reached its maximum value. Peel thickness was reduced during ripening from 3.1mm at MS1 to $1.6 \mathrm{~mm}$ in MS7 (data not shown), fact related to peel water loss to the atmosphere due to transpiration, and to the pulp, due to the increase of soluble solids in the pulp (DADZIE and ORCHARD, 1997). This transformation is particularly important for fruit handling since they become more susceptible to peel damages that can accelerate water loss and depreciate fruit appearance due to blackening of the spot of the injury (DEL AGUILA et al., 2010). However, the thin peel also leads to high pulp yield as observed for 'BRS Caipira' (Table 2), which is an advantage for consumers or even for processing.

The transition between MS2 and MS3 was important due to a high increase in soluble solids content, which kept significantly increasing until MS5 (Table 2). However, between MS6 and MS7, a 2-day transition, titratable acidity was nearly reduced in half with a significant increase in $\mathrm{pH}$ and SS/AT ratio, which would give the consumer the sensation of a sweeter fruit. These characteristics, together with the thin peel and high pulp yield, could be favorable for consumption or for processing (MATSUURA et al., 2004). Similar trends in acidity, soluble solids and $\mathrm{pH}$ have been reported for 'Caipira' and other Maçã-type bananas (CARVALHO et al., 2011) and 'Prata' and 'Nanicão' (NASCIMENTO JÚNIOR et al., 2008).

\section{Cold storage potential study}

Cold storage affected fruit ripening. The longer the storage under refrigeration, the shorter the period of time necessary for fruit to reach MS6 after transfer to room temperature (Table 3). Total storage time to reach MS6 was extended by five to 19 days due to cold storage when compared with control (no cold storage), without chilling injury to the fruit. However, the longest postharvest life extension was observed for fruit cold stored for 28 days, which already were in MS6 when transferred to room temperature. Therefore, it is evident that the ripening process continued even under lower temperatures,

Table 1 - Physical attributes of 'BRS Caipira’ banana fruit. Embrapa Mandioca e Fruticultura, Cruz das Almas, BA, 2012.

\begin{tabular}{|c|c|c|c|c|c|c|}
\hline & $\begin{array}{c}\text { Fruit weight } \\
\text { (g) }\end{array}$ & $\begin{array}{l}\text { Fruit length } \\
(\mathrm{cm})\end{array}$ & $\begin{array}{l}\text { Fruit diameter } \\
\qquad(\mathrm{mm})\end{array}$ & $\begin{array}{l}\text { Pulp weight } \\
\text { (g) }\end{array}$ & $\begin{array}{l}\text { Pulp diameter } \\
\text { (mm) }\end{array}$ & $\begin{array}{c}\text { Peel thickness } \\
\text { (mm) }\end{array}$ \\
\hline Mean & 96.2 & 14.3 & 35.0 & 72.7 & 30.3 & 2.3 \\
\hline CV (\%) & 17.7 & 12.2 & 7.6 & 17.2 & 7.8 & 34.4 \\
\hline
\end{tabular}


Table 2 - 'BRS Caipira' banana fruit ripening: time to reach maturity stages and respective quality attributes. Embrapa Mandioca e Fruticultura, Cruz das Almas, BA, 2012.

\begin{tabular}{|c|c|c|c|c|c|c|c|}
\hline Maturity stage & $\begin{array}{l}\text { Time to reach } \\
\text { the maturity } \\
\text { stage (days) }\end{array}$ & $\begin{array}{l}\text { Pulp to peel } \\
\text { ratio }\end{array}$ & $\begin{array}{l}\text { Pulp yield } \\
(\% \mathrm{w} / \mathrm{w})\end{array}$ & $\begin{array}{l}\text { Soluble } \\
\text { solids content } \\
\text { - SS (\%) }\end{array}$ & $\begin{array}{c}\text { Titratable } \\
\text { acidity - TA } \\
\text { (\% malic } \\
\text { acid) }\end{array}$ & $\begin{array}{c}\text { Ratio } \\
\text { (SS/TA) }\end{array}$ & $\mathrm{pH}$ \\
\hline MS1 & 0.0 & $2.03 \mathrm{e}^{1}$ & $66.9 \mathrm{e}$ & $3.2 \mathrm{c}$ & $0.23 b$ & $14.8 \mathrm{~d}$ & 4.84ab \\
\hline MS2 & 5.5 & $2.29 d$ & $69.6 \mathrm{~d}$ & $5.9 \mathrm{c}$ & $0.32 \mathrm{a}$ & $18.2 d$ & $4.72 b$ \\
\hline MS3 & 6.4 & $2.24 d$ & 69.0d & $13.3 b$ & $0.45 a$ & $29.7 \mathrm{~cd}$ & $4.43 b$ \\
\hline MS4 & 7.3 & $2.56 c$ & $71.8 \mathrm{c}$ & $14.0 \mathrm{~b}$ & $0.41 \mathrm{a}$ & 35.1bcd & $4.40 \mathrm{~b}$ \\
\hline MS5 & 8.1 & $2.71 b c$ & $73.0 \mathrm{bc}$ & $18.6 \mathrm{a}$ & $0.40 \mathrm{a}$ & $47.9 \mathrm{bc}$ & $4.60 \mathrm{~b}$ \\
\hline MS6 & 9.0 & $2.88 \mathrm{~b}$ & $74.0 \mathrm{~b}$ & $20.3 a$ & $0.39 a$ & $54.2 \mathrm{~b}$ & $4.68 \mathrm{~b}$ \\
\hline MS7 & 11.0 & $4.15 \mathrm{a}$ & $80.5 a$ & $18.9 \mathrm{a}$ & $0.20 \mathrm{~b}$ & $96.5 \mathrm{a}$ & $5.32 \mathrm{a}$ \\
\hline
\end{tabular}

${ }^{1}$ Means followed by the same letter in the column do not differ by the Tukey's test at 5\% probability.

although in a slower pace. This was expected since $14^{\circ} \mathrm{C}$ is an adequate temperature for banana storage and do not block fruit metabolism (PAYASI \& SANWAL, 2010). Similarly, 'Prata Anã' banana harvested at different ages and cold stored also did not have ripening blocked and starch degradation occurred during storage (MARTINS et al., 2007).

The practical implication of these results is that there is a limit for cold storage at $14^{\circ} \mathrm{C}$ for 'BRS Caipira' fruit. Based on these results, this limit is of 21 days to allow at least three days of commercialization under room temperature before reaching MS6. The necessity of a longer period of time under room temperature so that fruit can complete its ripening process is very important from a commercial point of view since banana consumers prefer fruit with longer postharvest life (MATSUURA et al., 2004). Moreover, since 'BRS Caipira’ was first recommended for cultivation in the Amazon region, which has a tropical climate with high average temperatures, refrigeration could be a necessity to extend shelf life and the possibility of reaching distant markets in Brazil or even neighbor countries.
Although some differences have been observed (Table 3), a clear effect of cold storage on fruit titratable acidity was not observed in this study. However, soluble solids content tends to be reduced in ripe fruit (MS6) with longer cold storage periods (Table 3). As observed for 'Prata-Anã' banana fruit (MARTINS et al., 2007; FERNANDES et al., 2010), cold storage possibly affected starch to sugar conversion, a process that explains most of the soluble solids accumulation in banana (DER AGOPIAN et al., 2011). These observations support the need to limit cold storage of 'BRS Caipira' to offer better quality fruits to the consumers.

\section{CONCLUSION}

Ripening of 'BRS Caipira' fruits was characterized as slow between MS1 and MS2 (averaging five days), then fast until MS6 (up to four days in average) and undergoing determinant changes from MS6 to MS7.

Maximum cold storage period at $14^{\circ} \mathrm{C}$ recommended for 'BRS Caipira' is of 21 days.

Table 3 - Time to reach MS6, total days of storage, soluble solids content and titratable acidity of ripe (MS6), cold stored 'BRS Caipira' banana fruit after transfer to room temperature. Embrapa Mandioca e Fruticultura, Cruz das Almas, BA, 2012.

\begin{tabular}{lcccc}
\hline Cold storage (days) & $\begin{array}{c}\text { Time to reach MS6 under } \\
\text { room temperature (days) }\end{array}$ & $\begin{array}{c}\text { Total storage time (days) } \\
\text { (\%) }\end{array}$ & $\begin{array}{c}\text { Soluble solids content - SS } \\
\text { (\%) }\end{array}$ & $\begin{array}{c}\text { Titratable acidity - TA } \\
\text { (\% malic acid) }\end{array}$ \\
\hline 0 & 9 & 9 & $19.7 \mathrm{ab}^{1}$ & $0.30 \mathrm{ab}$ \\
7 & 7 & 14 & $20.1 \mathrm{a}$ & $0.29 \mathrm{ab}$ \\
14 & 5 & 19 & $19.4 \mathrm{abc}$ & $0.33 \mathrm{a}$ \\
21 & 3 & 24 & $18.5 \mathrm{bc}$ & $0.22 \mathrm{~b}$ \\
28 & 0 & 28 & $18.2 \mathrm{c}$ & $0.25 \mathrm{ab}$ \\
\hline
\end{tabular}

\footnotetext{
${ }^{1}$ Means followed by the same letter in the column do not differ by the Tukey’s test at 5\% probability.
} 


\section{ACKNOWLEDGMENTS}

The authors would like to thank Embrapa for the finantial support for this study and for the M.Sc. scholarship for the second author; to FAPESB for undergraduate scholarship for the first author (BOL1086/2012, pedido 4116/2012); and for Helen Luise de Jesus dos Santos, for helping with fruit analyses.

\section{REFERENCES}

CARVALHO, A.V. et al. Qualidade pós-colheita de cultivares de bananeira do grupo 'Maçã', na região de Belém - PA. Revista Brasileira de Fruticultura, Jaboticabal, v.33, n.4, p.10951102, 2011. Disponível em: <http://dx.doi.org/10.1590/S010029452011000400007>. Acesso em: 09 jan. 2014. doi: 10.1590/ S0100-29452011000400007.

CERQUEIRA, R.C. et al. Características pós-colheita de frutos de genótipos de bananeira (Musa spp.). Revista Brasileira de Fruticultura, Jaboticabal, v.24, n.3, p.654-657, 2002. Disponível em: <http://dx.doi.org/10.1590/S0100-29452002000300020>. Acesso em: 09 jan. 2014. doi: 10.1590/S0100-29452002000300020.

CORDEIRO, Z.J.M.; MATOS, A.P. Manejo de doenças. In: BORGES, A.L.; SOUZA, L.S. (Eds.). Produção orgânica de fruteiras tropicais - ênfase nas culturas de abacaxi e banana. Cruz das Almas: Embrapa Mandioca e Fruticultura, 2010. 75p. Disponível em: <http://www. cnpmf.embrapa.br/publicacoes/documentos/documentos_197.pdf > Acesso em: 09 jan. 2014

DADZIE, B.K.; ORCHARD, J.E. Routine post harvest screening of banana/plantain hybrids: criteria and methods. Wageningen, The Netherlands: INIBAP Technical Guidelines 2. International Plant Genetic Resources Institute, Rome, Italy; International Network for the Improvement of Banana and Plantain, Montpellier, France; ACP-EU Technical Centre for Agricultural and Rural Cooperation, 1997. 75p. Disponível em: <http://www.bioversityinternational.org/e-library/publications/ detail/routine-post-harvest-screening-of-bananaplantain-hybridscriteria-and-methods/>. Acesso em: 09 jan. 2014.

DELAGUILA, J.S. et al. Postharvest modifications of mechanically injured bananas. Revista Iberoamericana de Tecnología Postcosecha, Hermosillo, v.10, n.2, p.73-85, 2010. Disponível em: $<$ http://www.redalyc.org/articulo.oa?id=81315091003>. Acesso em: 09 jan. 2014.

DER AGOPIAN, R.G. et al. Low temperature induced changes in activity and protein levels of the enzymes associated to conversion of starch to sucrose in banana fruit. Postharvest Biology and Technology, Amsterdam, v.62, p.133-140, 2011. Disponível em: $<$ http://dx.doi.org/10.1016/j.postharvbio.2011.05.008>. Acesso em: 09 jan. 2014. doi: 10.1016/j.postharvbio.2011.05.008.

DOCHEZ, C. et al. Screening Musa germplasm for resistance to burrowing nematode populations from Uganda. Genetic Resources and Crop Evolution, Netherlands, v.60, n.1, p.367-375, 2013. Disponível em: <http://dx.doi.org/10.1007/s10722-012-9841-7>. Acesso em: 09 jan. 2014. doi: 10.1007/s10722-012-9841-7.

FERNANDES, E.G. et al. Climatização e armazenamento refrigerado na qualidade pós-colheita de bananas 'Nanicão'. Bragantia, Campinas, v.69, n.3, p.735-743, 2010. Disponível em: <http://dx.doi.org/10.1590/S0006-87052010000300027>. Acesso em: 09 jan. 2014. doi: 10.1590/S0006-87052010000300027.
FERREIRA, D.F. Sisvar: a computer statistical analysis system. Ciência e Agrotecnologia, Lavras, v.35, n.6, p.1039-1042, 2011. Disponível em: <http://www.scielo.br/scielo.php?pid=S141370542011000600001\&script=sci_arttext $>$. Acesso em: 09 jan. 2014. doi: 10.1590/S1413-70542011000600001.

IBGE. Produção Agrícola Municipal, 2010. Disponível em: <http://www.sidra.ibge.gov.br>. Acesso em: 04 out. 2012.

LICHTEMBERG, L.A.; LICHTEMBERG, P.S.F. Avanços na bananicultura brasileira. Revista Brasileira de Fruticultura, Jaboticabal, v. especial, p.E.029-036, 2011. Disponível em: <http:// dx.doi.org/10.1590/S0100-29452011000500005>. Acesso em: 09 jan. 2014. doi: 10.1590/S0100-29452011000500005.

MARTINS, R.N. et al. Armazenamento refrigerado de banana 'Prata anã' proveniente de cachos com 16,18 e 20 semanas. Ciência e Agrotecnologia, Lavras, v.31, n.5, p.1423-1429, 2007. Disponível em: <http://dx.doi.org/10.1590/S141370542007000500023>. Acesso em: 09 jan. 2014. doi: 10.1590/ S1413-70542007000500023.

MATSUURA, F.C.A.U. et al. Marketing de banana: preferências do consumidor quanto aos atributos de qualidade dos frutos. Revista Brasileira de Fruticultura, Jaboticabal, v.26, n.1, p.4852, 2004. Disponível em: <http://dx.doi.org/10.1590/S010029452004000100014>. Acesso em: 09 jan. 2014. doi: 10.1590/ S0100-29452004000100014.

MENDONÇA, K.H. et al. Avaliação de genótipos de bananeira em Goiânia, estado de Goiás. Revista Ciência Agronômica, Fortaleza, v.44, n.3, p.652-660, 2013. Disponível em: <http:// dx.doi.org/10.1590/S1806-66902013000300030>. Acesso em: 09 jan. 2014. doi: 10.1590/S1806-66902013000300030.

NASCIMENTO JÚNIOR, B.B. et al. Diferenças entre bananas de cultivares Prata e Nanicão ao longo do amadurecimento: características físico-químicas e compostos voláteis. Ciência e Tecnologia de Alimentos, Campinas, v.28, n.3, p.649-658, 2008. Disponível em: <http://dx.doi.org/10.1590/S010120612008000300022>. Acesso em: 09 jan. 2014. doi: 10.1590/ S0101-20612008000300022.

PAYASI, A.; SANWAL, G.G. Ripening of climacteric fruits and their control. Journal of Food Biochemistry, Hoboken, v.34, p.679-710, 2010. Disponível em: <http://dx.doi.org/10.11 11/j.1745-4514.2009.00307.x>. Acesso em: 09 jan. 2014. doi: 10.1111/j.1745-4514.2009.00307.x.

PBMH \& PIF - Programa brasileiro para a modernização da horticultura \& Produção Integrada de Frutas. Normas de Classificação de Banana. São Paulo: CEAGESP, 2006. (Documentos, 29). Disponível em: <www.ceagesp.gov.br/ produtor/classific/fc_banana>. Acesso em: 09 jan. 2014.

PEREIRA, L.V. et al. Avaliação de cultivares e hibridos de bananeira em lavras, MG. Ciência e Agrotecnologia, Campinas, v.27, n.1, p.17-25, 2003. Disponível em: <http://dx.doi. org/10.1590/S1413-70542003000100002>. Acesso em: 09 jan. 2014. doi: 10.1590/S1413-70542003000100002.

SILVA, S.O. et al. Programa de melhoramento de bananeira no Brasil - Resultados recentes. Cruz das Almas: Embrapa Mandioca e Fruticultura, 2003. 36p. 
SILVA, S.O. et al. Variedades. In: BORGES, A.L.; SOUZA, L.S. (Eds.). O cultivo da bananeira. Cruz das Almas: Embrapa Mandioca e Fruticultura, 2004. p.45-58. Disponível em: <http:// www.cnpmf.embrapa.br/publicacoes/Livro_Banana.pdf >. Acesso em: 09 jan. 2014
XIAO, Y. et al. Banana ethylene response factors are involved in fruit ripening through their interactions with ethylene biosynthesis genes. Journal of Experimantal Botany, Lancaster, v.64, n.8, p.2499-2510, 2013. Disponível em: <http://dx.doi.org/10.1093/ jxb/ert108 >. Acesso em: 09 jan. 2014. doi: 10.1093/jxb/ert108.

Ciência Rural, v.44, n.4, abr, 2014. 